\title{
HEPATITIS B; ACQUAINTANCE AND PREVENTION IN BEAUTY THERAPISTS, PESHAWAR
}

\author{
Shaista Rasool ${ }^{1}$, Syed Imran Gillani² ${ }^{2}$ Saira Afridi ${ }^{3}$
}

\section{ABSTRACT:}

\section{OBJECTIVES:}

To assess the knowledge and practices of beauty therapists regarding hepatitis $B$ virus.

\section{METHODOLOGY:}

A cross-sectional study conducted on beauty therapists of Peshawar. It was an interview-based questionnaire. Beauty therapists were investigated about hepatitis $B$ transmission, vaccination, sterilization, use of gloves, and sterile equipment. Data was collected from most of the beauty salons of Peshawar. Data was analysed using SPSS 17.

\section{RESULTS:}

Around $90.6 \%$ therapists reported that they have knowledge about hepatitis $B$ transmission by reuse of pointers (needles), $56.1 \%$ identified that vaccine can prevent hepatitis $B, 98.7 \%$ beauty therapists that were interviewed reported exposure to blood during their work. $14.3 \%$ reported using gloves and $19.4 \%$ reported using only aprons. $20.4 \%$ of beauty therapists claimed sterilizing their instruments between clients, $51.4 \%$ reused needles whereas $88 \%$ reused orange sticks.

\section{CONCLUSION:}

Alertness about hepatitis and risks of transmission among beauty therapists is minimum, and their repetition of needles and inappropriate cleaning of tools is one of the reasons to spread hepatitis, which is widespread.

KEYWORDS: Beauty Therapists, Hepatitis B, Transmission, Piercing, Barbers, Beauty Industry, Tattooist

How to cite this article:

Rasool S, Gillani SI, Afridi S. Hepatitis B; acquaintance and prevention in beauty therapists,

Peshawar. J Gandhara Med Dent Sci. 2020;6(2):22-29. doi: 10.37762/jgmds.6-2.95 


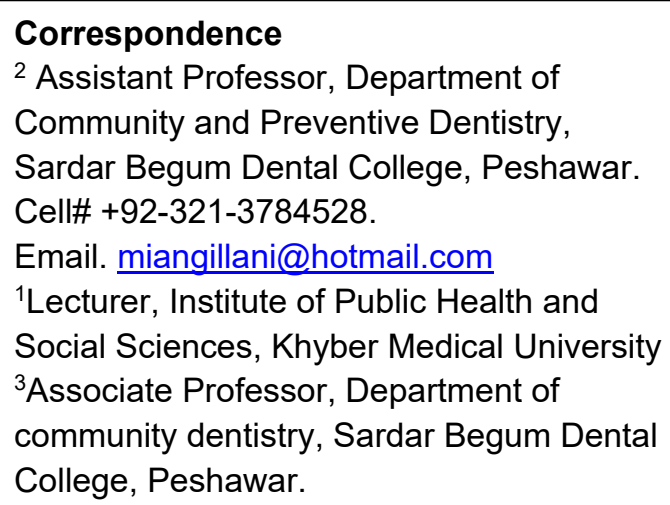

${ }^{2}$ Assistant Professor, Department of Community and Preventive Dentistry, Sardar Begum Dental College, Peshawar. Cell\# +92-321-3784528.

Email. miangillani@hotmail.com

${ }^{1}$ Lecturer, Institute of Public Health and Social Sciences, Khyber Medical University ${ }^{3}$ Associate Professor, Department of community dentistry, Sardar Begum Dental College, Peshawar.

\section{INTRODUCTION:}

The beauty industry has been identified as a potential risk factor for the spread of Hepatitis B and Hepatitis C virus in various parts of the world such as Pakistan, Italy and Japan $^{1-3}$. The transmission of HBV infection through blade allocation, tattooing, piercing, beauty treatments and manicure/chiropody might be considered significant hazard issues in advanced and emergent areas ${ }^{4,5}$. Hepatitis B is the most serious type of viral hepatitis and is a potentially lifethreatening liver infection. Worldwide 2 billion populations are infected with hepatitis B virus, of which 350 million are chronic hepatitis $B$ virus patients. Hepatitis B is the 10th leading cause of deaths worldwide, with 500,000 to 1.2 million deaths every year due to chronic hepatitis and cirrhosis, and 320,000 deaths every year due to hepatocellular carcinoma. The hepatitis B virus can live outside the body for one week (7-days) and can be source of infection; this combined with its high sero-conversion has made it of a concern for occupational transmission ${ }^{6,7}$. In Pakistan, around 7 to 9 million people have HBV with an estimated $3 \%$ to $5 \%$ carrier rate ${ }^{8}$. The high concentration of hepatitis $B$ virus in blood of infected people makes its transmission in work settings very easy. It can be transmitted by personal care procedures and the equipment used in beauty salons for different purposes. The virus can cause infection even when minute amount of blood, invisible to the naked eye breaks on the equipment and meets broken skin, mucous membrane, and rash ${ }^{9}$. Many factors can influence awareness of hepatitis ${ }^{10,}{ }^{11}$. The workers at these salons are usually ignorant of the various modes of transmission of infectious agents. The transmission of blood borne viruses can occur through eye splash, percutaneous injury or non-intact skin. Usually the same instruments are used for different customers without properly sterilizing them and this poses a potential risk in the spread of blood borne viruses. Furthermore, beauty therapists have minimum knowledge to latest information on occupational health and safety. This combined with the lack of regulation and provision for the execution of occupational health and safety measures has placed these workers and their clients at the risk of infections. Even though beauty treatments can contribute to the spread of hepatitis, there are only a few articles in literature regarding beauty therapy industry and hepatitis transmission ${ }^{12}$.

\section{METHODOLOGY:}

It was a cross-sectional survey conducted in Peshawar city that included the area under Municipal Corporation, Cantonment Board and 
Peshawar Development Authority. Study duration was three months. Study population included all beauty therapists working in beauty parlor/salon situated in Peshawar city. Through snowball sampling, 50 beauty salons list was obtained for this study. Of these 50 salons, 25 were selected by simple random technique. From these 25 beauty salons, 98 beauty therapists were interviewed for this survey based on simple random technique. All males and those beauty therapists who were not willing to participate, beauty therapists who were medical professionals like doctors, nurses, dispensers etc. were also excluded from the study. Similarly, those beauty therapists who had their salon attached to the clinic of a dermatologist were also excluded from the study. Data was collected through interview using a structured questionnaire, which comprised of demographics, awareness about hepatitis B and practices. Questions regarding awareness about hepatitis $B$ included knowledge about the possible modes of transmission of hepatitis $B$, symptoms of hepatitis $B$, and knowledge about prevention of hepatitis B. Data was analyzed using SPSS version 17.0. Continuous variables like age, duration of experience was described as Mean and Standard Deviation. Whereas categorical variables like questions about knowledge and practices were described as frequencies and percentages. Data was presented in tables and figure. To determine association between sociodemographic variables, knowledge and practices; Chi-square test at 5\% significance level was used.

\section{RESULTS:}

Response of the beauty salons was 100 per cent. Out of these $67.3 \%$ were single, $26.5 \%$ were married, whereas $6.1 \%$ were separated. $16.3 \%$ did not obtain any formal education, $25.5 \%$ received primary education, $15.3 \%$ received middle education, and 26.5 received education up to matric, whereas the remaining $16.3 \%$ were educated to secondary and above. The median age of this study group was 24 years. It was found that $53.1 \%$ of these beauty therapists were in this profession only for the last 1 year to 6 months, $20.4 \%$ were in this profession for the last 2 years, whereas the remaining $26.5 \%$ were in this profession for more than 2 years. One to five clients as compared to twenty clients per day, practices varied. Of the 98 beauty therapists that were interviewed $20.4 \%$ had one to five clients per day, $33.7 \%$ had six to ten clients per day, $37.7 \%$ had eleven to twenty clients per day and the remaining $3.1 \%$ dealt with more than twenty clients per day. Beauty therapist were asked if they had heard about hepatitis B and $99 \%$ responded with a yes. $75.5 \%$ of the 98 beauty therapists that were interviewed termed hepatitis B as a curable disease. $56.1 \%$ were aware that hepatitis $B$ is a preventable disease and that a vaccine is available for protection against the virus, whereas $36.7 \%$ were unaware of hepatitis $B$ vaccine. 
Table 1: Knowledge Regarding Hepatitis B

\begin{tabular}{|l|c|c|}
\hline & Frequency & Percentage of Cases \\
\hline Modes of Transmission & 45 & 14.1 \\
\hline Sneezing & 46 & 14.4 \\
\hline Coughing & 32 & 10.0 \\
\hline Sharing towels & 50 & 15.7 \\
\hline Sharing toothbrushes & 21 & 6.6 \\
\hline Sharing coffee/tea cups & 29 & 9.1 \\
\hline Sharing cutlery & 88 & 27.6 \\
\hline Needle prick & 4 & 1.6 \\
\hline Don't know & 3 & 0.9 \\
\hline No response & 318 & 100 \\
\hline Total & \multicolumn{2}{|l|}{} \\
\hline Is Hepatitis B Curable? & 74 & 76.3 \\
\hline Yes & 21 & 21.6 \\
\hline No & 3 & 2.1 \\
\hline Don't Know & 98 & 100 \\
\hline Total & 56 & 56.7 \\
\hline Is There a Vaccine Available for Protection Against Hepatitis B? \\
\hline Yes & 36 & 37.1 \\
\hline No & 6 & 6.2 \\
\hline Don't Know & 98 & 100 \\
\hline Total & \multicolumn{2}{|l|}{} \\
\hline
\end{tabular}

Of the 98 beauty therapists that were interviewed $2 \%$ had suffered from hepatitis B, whereas only $8.2 \%$ were vaccinated against hepatitis $B$. Only $8.2 \%$ of beauticians responded that they got information about hepatitis B and precautionary measures related to blood stumbles at their workplace, whereas the remaining $90.8 \%$ reported no information was given to them about hepatitis $B$, neither were they given any information on how to protect themselves or their clients from hepatitis B.

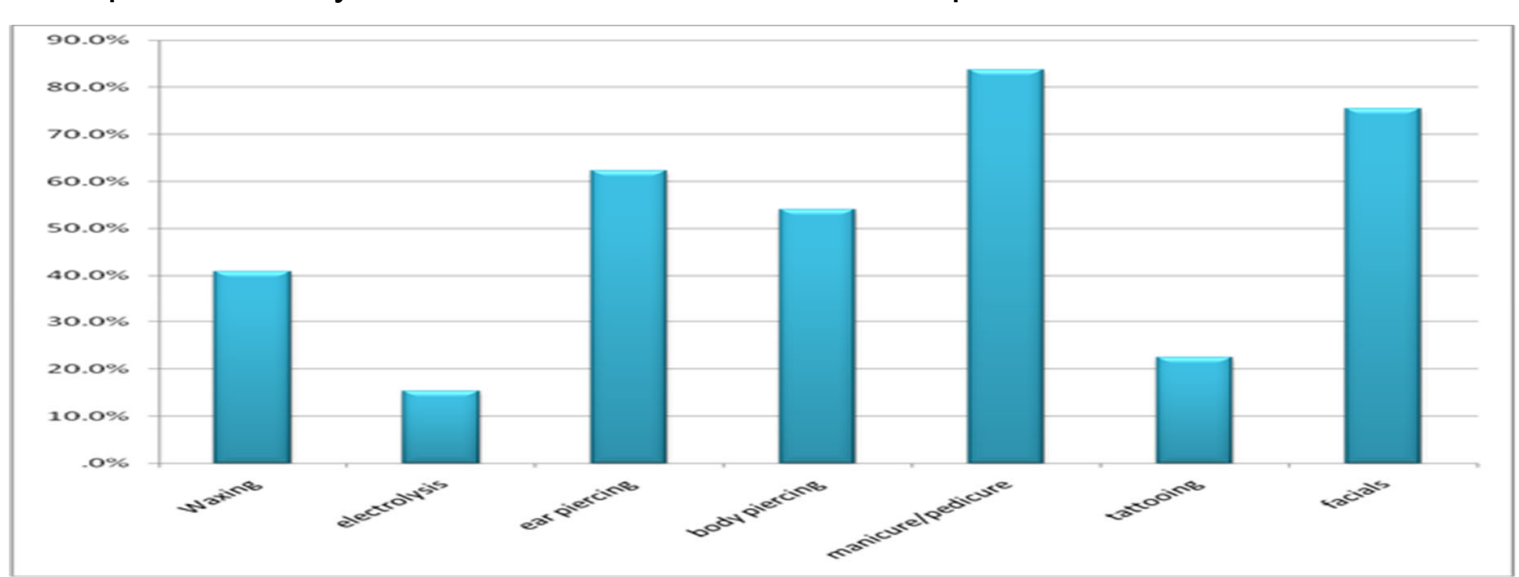

Figure 1: Reported Exposure to Blood During Procedures 
Table 2: Association of Knowledge with Education and Experience

\begin{tabular}{|c|c|c|c|c|c|}
\hline & & \multicolumn{2}{|c|}{ Education } & \multirow[b]{2}{*}{ Total } & \multirow{2}{*}{$\begin{array}{c}\text { Significance } \\
\text { level }\end{array}$} \\
\hline & & $\begin{array}{c}\text { Matric } \\
\text { and above }\end{array}$ & Below Matric & & \\
\hline \multirow{2}{*}{$\begin{array}{l}\text { Knowledge } \\
\text { about Hepatitis } \\
\text { B }\end{array}$} & Adequate & 5 & 5 & 10 & \multirow[b]{2}{*}{$<0.05$} \\
\hline & Inadequate & 37 & 51 & 88 & \\
\hline \multirow[t]{3}{*}{ Total } & & 42 & 56 & 98 & \multirow[b]{3}{*}{$\begin{array}{c}\text { Significance } \\
\text { level }\end{array}$} \\
\hline & & \multicolumn{2}{|c|}{ Experience } & & \\
\hline & & $\begin{array}{c}2 \text { years or } \\
\text { more }\end{array}$ & $\begin{array}{l}\text { Less than or } \\
\text { equal to } 1 \\
\text { year }\end{array}$ & Total & \\
\hline \multirow{2}{*}{$\begin{array}{l}\text { Knowledge } \\
\text { about } \\
\text { Hepatitis B }\end{array}$} & Adequate & 7 & 3 & 10 & \\
\hline & Inadequate & 38 & 50 & 88 & $<0.05$ \\
\hline \multicolumn{2}{|l|}{ Total } & 45 & 53 & 98 & \\
\hline
\end{tabular}

Table 3: Knowledge Regarding Prevention of Hepatitis B

\begin{tabular}{|l|c|c|}
\hline $\begin{array}{c}\text { How do you avoid contact } \\
\text { with blood at work? }\end{array}$ & Frequency & Percentage of Cases \\
\hline Gloves & 14 & 14.3 \\
\hline Apron & 19 & 19.4 \\
\hline Gloves and apron & 11 & 11.2 \\
\hline Mask & 8 & 8.2 \\
\hline Gloves, apron and mask & 2 & 2.0 \\
\hline Do Nothing & 43 & 43.9 \\
\hline No response & 1 & 1.0 \\
\hline Total & 98 & 100 \\
\hline Do you clean instruments \\
before use on next client? & Frequency & Percentage of Cases \\
\hline Yes & 97 & 99.0 \\
\hline No & 1 & 1.0 \\
\hline Total & 98 & 100 \\
\hline How do you clean & & Percentage of Cases \\
instruments before use on & Frequency & 22.7 \\
\hline Wash with water & 23 & 50.5 \\
\hline Wash with disinfectant solution & 49 & 20.6 \\
\hline Sterilize & 20 & 6.2 \\
\hline Wash, disinfect, sterilize & 6 & 100 \\
\hline Total & 98 & Percentage of Cases \\
\hline $\begin{array}{c}\text { Do you use sterile } \\
\text { disposable needles? }\end{array}$ & Frequency & 42.86 \\
\hline Yes & 42 & 54.08 \\
\hline No & 53 & 3.06 \\
\hline No response & 3 & 100 \\
\hline Total & 98 & \\
\hline nal & & \\
\hline
\end{tabular}




\section{DISCUSSION:}

According to this study $90.7 \%$ of the beauty therapists had acquaintance that hepatitis B can spread by infected needles, whereas $80.4 \%$ had knowledge that hepatitis $B$ is a sexually transmitted disease. These results are strikingly similar to a study conducted in Italy, as according to this study nearly $90.3 \%$ hairdressers gave accurate response regarding infection ${ }^{13}$, whereas a similar study done in Rawalpindi revealed that only $13 \%$ of barbers were aware that hepatitis $B$ could be transmitted by parenteral route or by reuse of razor $^{14}$. In contrast, a study in Lahore reported that an alarmingly high percentage of saloon workers $(54 \%)$ did not know about transmission of hepatitis $\mathrm{B}^{15}$. Another study from Islamabad on barbers reported that only $38 \%$ had knowledge about hepatitis B transmission. This difference in findings may be attributed to the reason that in this study the knowledge of beauty therapists was assessed, whereas in the study done in Rawalpindi, barbers were studied, in which roadside barbers were also included, and these roadside barbers are mostly illiterate which might have influenced the findings of the study. Another reason might be the difference in the two segments of the same industry, beauty therapists and barbers. Apparently, beauty therapists seem to be more aware about viral hepatitis. In contrast, a study in Iran reported almost two third of the saloon workers had intermediate to poor knowledge about hepatitis $B^{10}$. A similar study in the same vicinity concluded that there was a marked difference in knowledge, attitude and practices between barbers from rural areas and urban areas ${ }^{16}$. This study demonstrated that although beauty therapists included in this study were aware of the spread of hepatitis through sexual and parenteral routes, there was still a lot of confusion in this regard. Needle stick injury $(90.7 \%)$ and sharing toothbrushes (51.5\%) were accurately identified as the potential means of spread. Many incorrectly identified routes of transmission i.e. sneezing $(47.4 \%)$, coughing $(47.4 \%)$, sharing towels (33\%), sharing coffee/teacups $(21.6 \%)$ and sharing cutlery $(29.9 \%)$. It indicates that a vast majority of beauty therapists are aware of the routes of transmission of hepatitis $B$, and this could be attributed to access to media exposure, as according to $61.9 \%$ of the beauty therapists the major source of information is television. Since most of beauty therapists revealed television as their source of knowledge, public health authorities can use this medium to target this population to create awareness. However, the reason behind poor practices despite knowing contaminated needles/instruments can spread the infection needs to be pondered upon. Another interesting finding of this study was that educational status did not significantly affect the level of knowledge of these beauty therapists, as of the total ten respondents who had adequate knowledge $50 \%$ had more than ten years of education, whereas the remaining $50 \%$ either 
had less than ten years of education or no education at all. $88 \%$ of those beauty therapists who had more than ten years of education had inadequate knowledge regarding hepatitis $B$. This might be attributed to the unproductive education system of our country, as health education is missing from the curriculum of schools and colleges. Furthermore, $80 \%$ beauty therapists revealed caring for a hepatitis $B$ positive relative as their essential source of knowledge. Contrary to these findings, a study done on barbers in Gujrat revealed that those respondents who had primary education were more aware of the health hazards associated with their profession as compared to those who had no formal education ${ }^{17},{ }^{18}$. Our study revealed that trend of vaccination was very low as $8.2 \%$ were vaccinated against hepatitis $B$. Similarly, only $4.1 \%$ of the beauty therapists had the practice of properly disposing the used blades/needles, whereas $95.9 \%$ did not dispose of used needles/razors properly. This poses a major health hazard, as in a city like Peshawar, scavengers tend to search garbage sites in the hope of finding something valuable, most of these scavengers are children, thus they too are at a risk of acquiring and spreading the infection. Similarly, not only the scavengers but the sweepers and waste handlers are also at a risk of acquiring infections.

\section{CONCLUSION:}

This study concluded that even though the knowledge of majority of salon workers was satisfactory, there practices were not. There were no formal trainings for the workers regarding occupational health and safety, or cross infection protocols. Poor infection control practices along with lack of regulations may lead to increase in the burden of disease.

\section{REFERENCES:}

1. Khaliq AA, Smego RA. Barber shaving and blood-borne disease transmission in developing countries. South African Med J. 2008;95(2):945.

2. Munir $A$, Khan MZ. Risk factors in the transmission of hepatitis $B$ and C: a study of 100 cases of chronic liver disease. Esculapio. 2005;1(2):912.

3. Waheed Y, Bin-Rahat T, Safi SZ, Qadri I. Epidemiological patterns and risk factors associated with hepatitis $B$ virus in Pakistani population. Asian Biomed. 2010;4(4):547-54.

4. Candan F, Alagözlü H, Poyraz Ö, Sümer $\mathrm{H}$. Prevalence of hepatitis $B$ and $C$ virus infection in barbers in the Sivas region of Turkey. Occup Med. 2002;52(1):31-4.

5. Luksamijarulkul $P$, Maneesri $P$, Kittigul L. Hepatitis B seroprevalence and risk factors among school-age children in a low socioeconomic community, Bangkok. Asia Pac J Public Health. 1995;8(3):158-61.

6. World Health Organization. Hepatitis B: factsheet WHO/204 [Internet]. Geneva: World Health Organization; 2008. Available from: http://www.who.int/mediacentre/facts heets/fs204/en/

7. Centers for Disease Control and Prevention. Hepatitis B FAQs for health professionals [Internet]. Atlanta: CDC; 2009. Available from: 
http://www.cdc.gov/hepatitis/HBV/HB Vfaq.htm\#overview

8. Ali M, Idrees M, Ali L, Hussain A, UrRehman I, Saleem S, et al. Hepatitis $B$ virus in Pakistan: a systematic review of prevalence, risk factors, awareness status and genotypes. Virol J. 2011; 8:102.

9. Centers for Disease Control and Prevention. Hepatitis C support project HCV advocate: hepatitis B; 2014.

http://www.hcvadvocate.org/hepatitis I hepB/HBV_Personal_Care_FS. $\mathrm{Html}$.

10. Ataei B, Shirani K, Alavian SM, Ataie $M$. Evaluation of knowledge and practice of hairdressers in women's beauty salons in Isfahan about hepatitis $B$, hepatitis $C$, and AIDS in 2010 and 2011. Hepat Mon. 2013;13(3): e6215.

11. Wu E, Chen X, Guan Z, Cao C, Rao $H$, Feng $B$, et al. A comparative study of patients' knowledge about hepatitis $C$ in the United States and in urban and rural China. Hepatol Int. 2015;9(1):58-66.

12. Mariano A, Mele A, Tosti ME, Parlato A, Gallo G, Ragni $P$, et al. Role of beauty treatment in the spread of parenterally transmitted hepatitis viruses in Italy. J Med Virol. 2004;74(2):216-20.

13. Amodio E, Di Benedetto MA, Gennaro L, Maida CM, Romano N. Knowledge, attitudes and risk of HIV, HBV and HCV infections in hairdressers of Palermo city (South Italy). European J Public Health. 2010;20(4):433-7.

14. Janjua NZ, Nizamy MA. Knowledge and practices of barbers about hepatitis $B$ and $C$ transmission in Rawalpindi and Islamabad. J Pak Med Assoc. 2004;54(3):116-9.

15. Ilyas U, Manzoor I, Shahbaz A, Jalil $H$, Sheikh M, Shafqat Z. Awareness and practice of safety measures related to transmission of hepatitis B \& $C$ among barbers and saloon workers of Lahore, Pakistan. Int J Comm Health Med Res. 2017;3(2):84-91.

16. Shah HU, Dar MK, Jamil AA, Atif I, Ali RJ, Sandhu AS, et al. Knowledge, attitudes and practices of hepatitis $B$ and $\mathrm{C}$ among barbers of urban and rural areas of Rawalpindi and Islamabad. J Ayub Med Coll Abbottabad. 2015;27(4):832-6.

17. Wazir MS, Mehmood S, Ahmed A, Jadoon HR. Awareness among barbers about health hazards associated with their profession. $\mathrm{J}$ Ayub Med Coll Abbottabad. 2008;20(2):35-8.

18. Khan A, Afzal S, Yaqoob A, Fatima R, Haq MU, Junaid K, Nadir A. Epidemiology of viral hepatitis $B$ and $\mathrm{C}$ in Punjab, Pakistan: a multicenter cross-sectional study, 2017-18. F1000Research. 2019 Dec 6;8(2065):2065.

\section{CONTRIBUTORS}

1. Shaista Rasool - Concept \& Design; Data Acquisition; Data Analysis/Interpretation; Drafting Manuscript; Critical Revision; Supervision; Final Approval

2. Syed Imran Gillani - Data Analysis/Interpretation; Drafting Manuscript; Supervision

3. Saira Afridi - Data Analysis/Interpretation; Critical Revision; Final Approval 